\title{
Spells of Moral Panic and Flashes of Pride: Digital Kinois' Engagements with the Search for a COVID-19 Cure
}

\author{
Katrien Pype
}

The search for an efficient cure for COVID-19 infections is a medical puzzle of global and local political significance. It is also readily felt in 'Digital Kinshasa', the online space for those who identify as a 'Kinois', an inhabitant of (global) Kinshasa. Digital Kinois ask questions such as how are 'black' bodies involved in this pandemic? What kind of expertise does the DRC, and by extension Africa, have in this crisis? And, can African herbal treatments play a role in CoviD-19? The answers Digital Kinois formulate on these questions are informed by their understandings of global inequalities and racist stereotypes. ${ }^{1}$

In the following, I describe the online discussions on the topic of COVID-19 care in Africa that occurred between 2O March and 12 May 2O2O, thus spanning the height of Covid-communication in Digital Kinshasa. By early May, one could observe a growing COVID fatigue in both Kinois society and in Digital Kinshasa due to a seeming lack of covid patients. I ask, what does 'the digital' afford Kinois in this era of uncertainty in the biomedical world and global chaos? It will become clear that several of these discussions have led to 'digital moments', periods of intensified digital content production around a topic. I have subdivided these into 'spells of moral panic' and 'flashes of African pride'. In these 'moments', motivated sometimes by disgust and rage, at other times by glorification and anticipation, a collective effervescence (Durkheim 1912) emerged, uniting Digital Kinois around a theme that mattered, while at the same time pushing forward debates, experimenting with new vernaculars, advancing new cultural heroes, defying established figures of authority, and imagining new futures.

Since 2003, I have been carrying out ethnographic research on media cultures in Kinshasa. The material has been collected via remote ethnography (Postill 2016), following public and private lists and publications on Facebook, Instagram, WhatsApp and YouTube, and privately interacting with individuals

1 A longer version of this chapter appeared as a UCL Centre for Digital Anthropology blog post (Pype 2020).

(C) KATRIEN PYPE, 2022 | DOI:10.1163/9789004471641_018

This is an open access chapter distributed under the terms of the CC BY-NC 4.0 License. 
over Messenger and WhatsApp. Most names of the interlocutors and commentators are pseudonyms, except for public figures. I have translated all posts from Lingala, French or KiKinois (Kinshasa's slang) into English.

\section{First Flash of African Pride: 'Blacks' Coming to Rescue 'Whites'}

On 21 March, Cuban nurses and doctors arrived in Italy. Zacharie Bababaswe, an influential Congolese television journalist, with a short history as national deputy, wrote on his Facebook wall:

Atterrissage d'un avion militaire cubain transportant des médecins du pays de Fidel Castro, en Italie. Tous sont des noirs accueillis en 'standing ovation' par des blancs. Les larmes d'incapacité du Président du Conseil italien ont ému le monde entier et Cuba a réagi. Qui l'aurait cru ? Le monde va changer après le Coronavirus !! \#SimonKimbangu"

[English translation: The arrival of a Cuban military plane transporting doctors from Fidel Castro's country to Italy. All of them are blacks receiving a 'standing ovation' from whites. The president of the Italian Council's tears of helplessness have moved the whole world and Cuba has reacted. Who would have believed it? The world will change after Coronavirus !! \#SimonKimbangu]

The caption of the text showed a sad emoji, along with the phrase that he was 'feeling emotional' (Bababaswe 2020).

The subtext is that the world is witnessing a reversal of the 'normal' relationships in global health. Black people are coming to the rescue of 'whites'. The question of 'Who would have believed it?' expresses joy in this disbelief; the hashtag \#SimonKimbangu adds a politico-religious layer to the statement. ${ }^{2}$ Bababaswe's hashtag made an explicit connection between the Cuban doctors' travel and Kimbangu's prophecy. Kimbangu is heralded as a 'father of

2 Simon Kimbangu, the so-called Black Jesus, is one of Congo's (and by extension Africa's) most important religious leaders. He is the founder of the Kimbanguist Church (official name: l'Eglise de Jésus-Christ sur la terre par son envoyé special Simon Kimbangu), arguably one of the largest African prophetic movements. Through his popularity as a healer Kimbangu quickly became an icon of colonial resistance and started a religious movement with strong political bearings. His prison notes, written while being detained by the Belgian colonial authorities, contain prophetic announcements of the liberation of the 'black race', and of an increasing role for black people on the global stage (M'Bokolo and Sabakinu 2014; Mokoko-Gampiot 2017). 
the nation', not only by Kimbanguist followers but by many non-Kimbanguist Congolese as well. It is thus not surprising that Bababaswe dropped Kimbangu's name in a post celebrating black pride.

Bababaswe was not the only one taking up Kimbangu's image during the first CoviD-19 weeks in Kinshasa (10-30 March), nor did he 'invent' a new practice. Rather, several Digital Kinois posted Kimbangu's iconic image as a temporary profile picture. Such association with Kimbangu, now in the digital sphere, echoes the above-mentioned admiration for Simon Kimbangu as one of the earliest black voices contesting white colonial powers, and one that one hears regularly when political sovereignty and cultural independence are discussed publicly and privately.

\section{Second Flash of African Pride: the Hype Around a Congolese} Herbal Treatment

From mid-April, for about a fortnight, 'Digital Kinshasa' was enchanted by the announcement of the herbal treatment covid-Organics (also called cvo and CVo-Organics), an infusion of Artemisia leaves. It all began with press reports, on 19 April, about Andry Rajoelina, the president of Madagascar, announcing that CoviD-Organics would be offered freely to Malagasy schoolchildren in the fight against CoviD-19. Malagasy media mentioned that the herbal remedy, already said to treat malaria, worked as a prophylaxis to prevent and cure COVID-19 infections.

Kinois eagerly remediated news reports about the Malagasy policy and called on the Congolese president to follow. The news generated new bouts of African pride. President Rajoelina's decision inspired hashtags calling for unity in Africa, sometimes the hashtags \#StopCovidig \#AfriqueUnie (translated \#UnitedAfrica); and \#ThisTimeForAfrica could appear in one and the same post.

Heightening the excitement, people shared screenshots showing Congolese President Tshisekedi and Malagasy President Rajoelina teleconferencing about 'solutions' for Covid-19 in Africa. Someone wrote under one of these screenshots "for the very first time Fatshi [the moniker Kinois commonly use to indicate their President] is making me happy", followed by a happy emoji, "that is how it should be done bravo ya fatshi", and closing with an emoji of praying hands.

The 'ya' is significant, as it is a form of address that expresses intimacy: ' $y a$ ' is shorthand for 'older brother' in Lingala (yayá). In this way, the poster expressed closeness to the president, and thus seemed to approve the latter's actions. 
Such a sign of endearment is remarkable in a climate of general distrust towards the national government. Did this signal that the hype could become a moment for the Congolese president to gain affection and support? One of my Facebook contacts remediated a YouTube link to an excerpt ${ }^{3}$ of the interaction between the two presidents and added the caption: "we will not wait for the wHO to tell us what to do, 6o years after independence.... D RC orders 5000 bottles of Covid-Organics in Madagascar. Felix Tshisekedi." Again, happy faces and praying hands punctuated the inscription.

In the midst of the hype that got so many Digital Kinois carried away, several people observed that international media were silencing CoviD-Organics. Digital Kinshasa agreed that this was due to the cowardice of Global North media reporters, who dared not go against wHO decisions. Thus, rather quickly, the Covid-Organics product became framed in a competition between the Global North and the Global South.

This inspired some to become self-confident and to write audacious statements. Rolly, for example, a technological entrepreneur and employee of one of the DRC's largest banks, published hashtags for the herbal remedy '\#CVO' and '\#COVID_19 Killer', accompanying the message "the Malagasy drink, wно will have to jazz along".

Others called to set up an 'African' agency of sanitary regulation and pharmacy. They did not only summon this on social media, but an online petition became popular as well (Rayan 2020). On its webpage, the wHo logo (oms in French) and a photograph of three covid-Organics (here cvo) bottles, were juxtaposed, visually reminding visitors about the conflict. By 10 May, the petition had already acquired more than 23,00o signatures.

Some Kinois argued that the discussion between 'Africa' and the wно regarding CoviD-Organics boils down to a discussion over 'tradition' versus 'modernity'. Other posts took the news about the herbal tea as an opportunity to formulate new possible futures for the continent.

Although international media ascribed ownership of covid-Organics to the Malagasy Institute of Applied Research, Digital Kinois found a way of making it a 'Congolese' invention. Very quickly, Digital Kinshasa argued that the real inventor was the Congolese Dr Jérôme Munyangi, who had apparently been working in Madagascar at that time. Until the third week of April, Dr Munyangi had been an anonymous fellow citizen to most Digital Kinois. By the end of the month, his name had become a household word, and most Kinois knew that he was a medical scientist, who had trained at the University of

3 In the meantime, the video has been deleted from the YouTube platform (last accessed on 28 September 2020). 
Kinshasa, in Paris, and at the University of Ottawa. Some liked to emphasize that Dr Munyangi was an asylum seeker in Madagascar. This information only increased the excitement. News circulated that a few years earlier, Dr Munyangi had been imprisoned for a few months in the DEMIAP (Détection Militaire des Activités Anti-Patrie/Military Detection of Antipatriotic Activities) detention centre in Kinshasa, notable for the brutal tortures that detainees, often political prisoners, underwent there. A visa delivered by the French embassy, so the story goes, had enabled him to escape and travel to the neighbouring Central African Republic, from where he could flee to Paris. In late 2018, French TV news studios invited him to appear in a documentary attacking the pharmaceutical industry.

Several videos, some self-recorded, some parts of Internet interviews with Kinois web journalists, circulated on social media. In these, Dr Munyangi explained that he had been arrested because dark forces in the global pharmaceutical business saw his tea as a threat. The product provides a cheap and easily accessible cure for malaria, one of the biggest health challenges in Africa, and thus would mean a significant loss for the big pharmaceutical companies. He mentioned his eagerness to return to Kinshasa and consult the government in the CoviD-19 battle, but requested protection from the Congolese state.

Dr Munyangi became 'the star of the moment' ('la star du moment'); his biography circulated in written form, sometimes some posters felt they had to correct the spelling of his name (not suffix '-i' but '-a'), or they added new information about his life; the overall mood was one of joy and anticipation. Dr Munyangi was applauded and cheered and, for the duration of the hype, he almost became a new cultural hero, despite or perhaps because wHo denied that the product had undergone the standard clinical testing. Digital Kinois reinforced his call for protection in writing and added a critique addressed to the Congolese government for having failed to protect him in 2018. Now, so they wrote, the government could make good that mistake.

Most Digital Kinois neither questioned the therapeutic efficacy of CovidOrganics, nor critically assessed Dr Munyangi's biography. Rather, they contributed to the promotion of the product by repeating the hashtags with the brand's name, posting the doctor's name, and showing pictures of the bottles. One person wrote in to say that Dr Munyangi "clearly had been contested too much by scientists who object [to] the indisputable results of his field experiences," while another commentator asked where he could find the plant, suggesting that he was definitely going to consume it.

By early May, some posts were announcing that Dr Munyangi was on his way to Kinshasa. In an attempt to substantiate the message, some added a 
picture of him at the Charles de Gaulle airport in Paris. Hardly any of my social media contacts appeared to question the truthfulness or foundations of these announcements; rather, most of the messages consisted of congratulations, good wishes and expressions of gratitude for his patriotism and his assumed contributions to the COVID-19 pandemic.

Not even a week later, the hype suddenly fizzled out and I stopped seeing publications bearing his or the product's name. However, on their online platforms a few newspapers mentioned that Dr Munyangi was still in Paris, but this information was rarely put on social media. One journal seemed to have interviewed him in early May. Under the heading "Covid-19: Announced to be in Kinshasa, Dr Muyangi still in Paris", the article was published online on 4 May, but did not attract much attention (Redaction 2020). A few days later, on 7 May, via Messenger one of my contacts forwarded me these reports and screenshots of an article in the online journal Benin Times describing adverse side effects Malagasy volunteers experienced from covid-Organics, which they had documented on social media (Kylian 20oo). These ranged from loss of general well-being, itching all over the body, sudden bouts of increased temperature, nightmares, nausea, headaches, and excessive urinating. None of my social media contacts circulated these screenshots on their (semi-) public pages, walls, profiles or statuses. The mere fact that I received this information privately, via the Messenger tool, is significant: it speaks to weighing up the publishability of content. The news report obviously countered the excitement that what by then an already faded hype had fuelled in 'Digital Kinshasa', and my contact, who hardly posts anything political on his social media platforms, told me that he risked accusations of being called 'anti-patriotic' or a party spoiler if he published these online.

Many online publications expressed an urge for a reappraisal of local scientific knowledge and innovation. For Kinois web users, CoviD-19 provided an opportunity to showcase 'African' knowledge and expertise. Reports about the contributions of Congolese scientists were readily absorbed, and these experts were explicitly identified as 'African', even if they were working in the Global North.

For example, on 12 April, Code 243, which collects online national and international news about the DRC ( 243 is the international area code), announced the contribution of a US-based Congolese engineer producing respirators to protect the DRC from COVID-19. In similar efforts to provide exposure to 'African' contributions to CoviD-19 care, Digital Kinois gladly shared reports about schools and institutions in Kinshasa producing medical equipment such as ventilators and face masks. 
As of 10 March, in the very first weeks that COVID-19 had arrived in Kinshasa, pictures of Kongo bololo circulated in Digital Kinshasa. Just like COVIDOrganics, Kongo bololo is a tisane (herbal tea) based on the leaves of Vernonia amygdalina. Many online commentators argued that Kongo bololo would prevent and cure COVID-19.

Some online commentators applauded Kongo bololo as 'the most efficient vaccine'; others heralded the local origins of the cure, and their familiarity with it. One of my friends wrote: "We have grown up with it! Return to authenticity; this is from our ancestors". This shout of 'return to authenticity' echoes former President Mobutu's programme to reinstate local tradition. That and the reference to the ancestors are discursive efforts to revalue cultural heritage in this global event.

Over the following two weeks, I noticed postings on Facebook and Instagram, or WhatsApp status updates carrying short clips or photographs of pots of boiling leaves (some with lemon parts). Yet, already by the last week of March, it had become clear that the concoction was doing more harm than good and warnings about deaths from drinking Kongo bololo quickly circulated online. Other publications claimed that a mother and her three small children had died from consuming a mixture of Kongo bololo and lemon. Reactions pointed at the toxic combination of the two ingredients, knowledge that was not apparently generally known.

(Digital) Kinois did not jettison all herbal treatments, as the earlier excitement about Artemisia suggests. What may explain people's hopes and expectations about the CoviD-Organics product, may be the involvement of the already-mentioned Dr Munyangi. I have no knowledge of any scientific expert having been consulted to vouch for or reject the therapeutic properties of Kongo bololo. Rather, all opinions about it were transmitted via informal, domestic channels occupied mainly by mothers and grandmothers. If my assumption is correct, then herbal products gain different, even opposing, values during periods of public anxiety, depending on the type of 'experts' involved. Because Dr Munyangi is presented as an expert in biomedical treatments, he can translate the healing properties of the Artemisia plant into biomedical language, and position himself within the global world of the big pharmaceutical companies. Embedding the Artemisia plant in the global, commercial politics of public health is fully in line with portraying COVID-19 as a global affliction. The subtext of the different perceptions on Kongo bololo and Artemisia seems to be that a disease with a cosmopolitan allure, such as COVID-19, calls for a 
treatment that carries equally cosmopolitan connotations, and all the more so if it originates from the African continent.

Second Spell of Moral Panic: Fear over Black Bodies Being Used as Guinea Pigs for the White Global Health Economy

On 4 April, Djora, an unemployed man with a degree in mechanical engineering, wrote on his Facebook page: "for everything, we [Congolese people] are waiting for 'the West' - ventilators, masks, thermoflash [digital thermometer], disinfecting and testing material, chloroquine, azithromycin, money; but if the West proposes to do a test, then you think he will kill you - he could have put that in the mask." Djora was pitting the Congolese community against an imagined West. He detected a certain ambiguity in Congolese attitudes. On the one hand, he recognized their dependency on Western equipment, but felt that when the West wants to run tests (thus calling on the Congolese people to make their contribution towards advancing scientific knowledge and developing medical treatments), then the Congolese people suspect the white man from the West of wanting to kill them. By saying, "he could have put that in the mask", Djora is reminding his readers that white men can find insidious ways of killing Congolese people, for example by putting toxins in the masks exported to the DRC.

Djora's comment reflects the fears and distrust about global health initiatives that Congolese populations have long held, and not without reason (see Hunt 2016; Lyons 1992). Many Kinois believe that medical interventions sponsored and/or carried out by people from the Global North are part of an evil plan by institutions like the World Bank, World Health Organization (WHO), Western governments, and Congolese state. Extractive procedures, such as collecting blood and DNA, and intrusive ones like injecting drugs, are seen as hidden attempts to damage people's fertility and life force, and to undermine African futures. This fear was most poignantly expressed in messages to mobilize people to refuse COVID-19 vaccine testing in the DRC. Most Kinois are in no doubt that testing sacrifices African lives. And, as I would read in various online posts, Bill Gates has become the anti-hero, the villain. Similar outrage was expressed on Facebook when two French doctors allegedly suggested testing vaccines on the African continent (Rossman 2020). This followed shortly after Congolese microbiologist and coordinator of the national response to COVID-19, Dr Muyembe, proudly announced at a press conference that the DRC had been chosen to partake in testing experiments for a vaccine. 
At the onset of the CoviD-19 pandemic, Dr Muyembe had accumulated a lot of credit in Kinshasa, as well as a worldwide reputation, for his impressive work during several Ebola pandemics in previous years. In 2014, he was one of the experts WHO sent to Nigeria to coordinate the Ebola campaign in West Africa and, such was his renown, that he was very much a local hero. However, the announcement that Congolese citizens would become guinea pigs radically turned him into an anti-hero.

On the Internet and in the streets of Kinshasa, people quickly engaged in conspiratorial thinking, ${ }^{4}$ despite similar tests being undertaken in the USA, China and Europe, and the DRC being one of many countries engaged in further testing. ${ }^{5}$ Someone wrote, "Muyembe announces, most probably from the premises of the embassy of the United States, that we have been chosen." The commentator emphasized that Dr Muyembe was delivering the message from a peculiar location: he was clearly not in his office, the National Institute of Biomedical Research (INRB), nor was he speaking from a Congolese state building. Rather, he was probably in the US embassy, thus suggesting that the US government had a hidden agenda in the testing.

A young woman, who described herself as a medical doctor, with a "degree from a Canadian university", thus claiming a certain authority in the matter, added fuel to the conspiracy discourse by saying: "No, no, no! Suddenly, a new disease has appeared, and they find a vaccine in six months? This story is fishy." Other commentators stated firmly that they would not allow tests to be carried out on their bodies or on those of their family members. A rare voice warned others to be careful of conspiracy theorists, adding that "China and the USA are already testing potential vaccines". Rolly, the technological engineer mentioned above, wrote "just like you all, I am indignant. But before I react, I need to know the list of countries chosen for the test of this vaccine. @Covid19." Someone else commented, "we are not the only ones who will be tested. ... Furthermore, how has Ebola been conquered? Thanks to a vaccine, created by whom? Professor Muyembe." Yet, such publications did not get any approval, nor did they gain any traction.

4 Conspirational thinking in the CoviD-era is not limited to the Digital Kinois. In the USA and Europe, for example, Bill Gates was accused of being involved in creating the virus to benefit his commercial interests (Gruzd and Mai 2020). The Kinois' conspiratorial stories were obviously based on reports that had originated elsewhere. I wish to thank an anonymous reviewer for noting the conjunction between global and local conspiracy theories.

5 As a reviewer remarked, many influential Africans spoke out against testing the vaccine in sub-Saharan Africa. Examples are Dr Tedros Adhanom Ghebreyesus, director general of the wно (ввC 2020), and the Ivorian footballer Didier Drogba (Rossman 2020). Though these figures did not appear as highly influential in Digital Kinois' musings about the vaccine. 
As part of the anti-vaccine mobilization, a hyperlink to a digital petition circulated, inviting people to sign "no! regarding anti-COVID 19 vaccination tests in Africa". By 10 May, an automatic counter on the petition's website announced more than 87,00o signatures (Toure n.d.). A Facebook post juxtaposed the scan of a letter issued by a Congolese representative of the World Bank next to a video of Dr Muyembe at a press conference. The document, with a World Bank in Washington letterhead and signed by "the administrator for the Democratic Republic of Congo", was addressed to the (Congolese) minister of finance. It confirmed that the advisory council of the World Bank had approved a loan of US\$23.6 million, and a similar gift (another US\$23.6 million). The goal, so the letter announced, was to assist the capacities of the Congolese state to respond to the COVID-19 pandemic.

The commentator did not seem to question the authenticity of the document and, by publishing the two documents next to the video, suggested that the millions of dollars went straight to Dr Muyembe rather than to the Congolese government. The caption stated it almost explicitly - "All of that because of an interest in millions." Most comments on this publication were dominated by resentment. Someone wrote, "shameful", while another added, "un négro de service" (a black man working for others), although one commentator brought some cheer to the exchange by proposing "and what if we would all cough on him?"

This spell of moral panic ended with a minor flash of pride and encouragement. The coordinating office of the fight against COVID-19 published a clip of 2:23 minutes on social media in which Dr Muyembe provided more transparency regarding the vaccine testing (Muyembe 2020). At the beginning of the video, he mentioned that he had seen various messages on social media talking about COVID-19 testing in the DRC. Speaking from his office at the INRB, he expressed the need to calm the population and assured them that, as a Congolese citizen himself, he would never allow the Congolese to be used as guinea pigs. Rather, "if there was going to be testing on the territory, it would be after the current tests in the United States and in China generated good results."

Various captions celebrated this announcement as a victory for social media - "the power of social media", or "the collective of social media has pushed \#Muyembe to shed more light on his propositions qualified as testing efforts." Reactions to this and similar digital content celebrated the influence that (Digital) Kinois seemed to exert over domestic politics. Some mentioned that the Congolese have become more demanding, and do not remain passive on issues of health politics. Often, such comments were accompanied by mobilizing shouts to stay vigilant, or reminded others that "we are in a war against Macron and Trump. This war has just begun, stop whining, we are 
now in the right position." For some commentators, Dr Muyembe's statement proved that the population was more powerful than the Congolese president, who - after all - remained silent amidst this whole moral panic. Still, others did not believe his words and continued on to what can only be described as a witch hunt. Since the moral panic about vaccine testing, Dr Muyembe has received death threats and has temporarily suspended his participation in live press conferences.

The above moments of moral panic and African pride contributed towards the unfolding CoviD-19 crisis in Kinshasa. They were socially significant because they gave definite form to Kinois' experiences, sentiments and expectations, from which one can conclude the following. First, online social networks are places in which to mobilize for an African-centred future through a figure of colonial resistance (Simon Kimbangu), African plants, a form of political participation (petitions), and a renewed interest in African futures. Second, online critiques of the global health system can reach a much larger audience: the absence or presence of care facilities and expertise are interpreted as manifestations of the racial imaginaries that govern global health. Most understood testing for COVID-19 as a new articulation of old forms of exploitation. In such a narrative, Bill Gates, wHO, and the World Bank are dangerous actors who are teaming up with their own Dr Muyembe. Third, it is clear that the digital world allows Kinois to rewrite the saviour narrative: some suggested that this crisis gives black (including Cuban) or African experts an opportunity to assume the saviour role. A narrative of confidence and optimism to the effect that Africans can care for themselves and even rescue whites reverberated. Social media then provided platforms from which to showcase those African inventions, or contributions of African engineers and medical doctors that remain largely invisible on the global scale. Finally, it is online that Kinois attempt to implement political change: the spells of moral panic and flashes of African pride were socially productive. They generated excitement, enthusiasm, agitation and disgust - all of which have immediate political ramifications. The effervescence generated digitally was performative: it unified people around common goals. Whether the public demanded more clarity on Congolese involvement in CoviD-19 testing, or whether people wanted to protect one another from false information (as in the case of Kongo bololo), Digital Kinois were trying to make an impact on their immediate surroundings, and on those of their (virtual) contacts. At times, the effervescence was disruptive. However, when it 
disturbed political alliances, it forced leaders to backtrack on certain decisions and it changed certain political practices.

\section{References}

Bababaswe Z. 2020. Facebook post, 23 March. https://www.facebook.com/zacharie. wishiya/posts/10157665653526677.

ввС. 2020. "Coronavirus: Africa will not be testing ground for vaccine, says WHO", ввС, 6 April. https://www.bbc.com/news/world-africa-52192184.

Durkheim, E. 1912. Les formes élémentaires de la vie religieuse. Paris: Presses Universitaires de France.

Gruzd, A. and P. Mai. 2020. "Going viral: How a single tweet spawned a COVID-19 conspiracy theory on Twitter". BigData \& Society, 7, 2:1-9.DOI:10.1177/2053951720938405.

Hunt, N. R. 2016. A nervous state: Violence, remedies and reverie in colonial Congo. Durham, NC: Duke University Press.

Kylian, A. 2000. "Revirement à Madagascar: Le Covid-Organics aurait des effets indésirables." La Vraie Info, 7 May. https://www.benintimes.info/international/revirement-a-madagascar-le-covid-organics-aurait-des-effets-indesirables/ [7 September 2020].

Lyons, M. 1992. The colonial disease:A social history of sleeping sickness in colonial Zaire, 1900-1940. Cambridge: Cambridge University Press.

M'Bokolo, E. and D. Sabakinu. (Eds). 2014. Simon Kimbangu: le prophète de la libération de l'homme noir. (Parts 1 and 2.) Paris, L'Harmattan.

Mokoko-Gampiot, A. 2017. Kimbanguism: An African understanding of the bible. University Park, PA: Penn State University Press.

Muyembe, J. J. 2020. "Le point sur la reiposte par le Docteur Muyembe." Comité multisectoriel de la riposte à la pandémie du Covid-19. YouTube video, 4 April. https:// www.youtube.com/watch?v=aGCuywaX4cA.

Postill, J. 2016. "Remote ethnography: Studying culture from afar." In The Routledge companion to digital ethnography, edited by L. Hjorth, H. Horst, A. Galloway and G. Bell, 61-69. Abingdon: Routledge.

Pype K. 2020. "Contributions from the Democratic Republic of the Congo (DRC). Spells of moral panic and flashes of pride: Digital Kinois' engagements with the search for a COVID-19 cure." UCL Centre for Digital Anthropology website. "Collecting COVID-19. A crowd-sourced digital ethnography of the COVID-19 pandemic." https://anthrocovid.com/3-2/contributions-from-the-democratic-republic-of-thecongo-drc/ [16 May 2020]. 
Rayan, H. 2020. "Signé cette pétition pour la création de l'organisation africaine de la santé (OAS)", online petition https://secure.avaaz.org/fr/community_petitions/ lunion_africaine_signe_cette__ petition_pour_la_creation_de_lorganisation_ africaine_de_la_sante_oas/ [4 June 2020].

Redaction. 2020. "Covid-19: Annoncé à Kinshasa, le docteur Jérôme Munyangi est encore à Paris." A la Une, 4 May. https://alaune.cd/covid-19-annonce-a-kinshasa -le-docteur-jerome-munyangi-est-encore-a-paris.html.

Rossman, R. 202O. "Racism row as French doctors suggest virus vaccine test in Africa". Al Jazeera, 4 April. https://www.aljazeera.com/news/2020/4/4/racism-row-as-french -doctors-suggest-virus-vaccine-test-in-africa [7 December 2020].

Toure, H. n.d. "NON! Aux tests de vaccins contre le COVID 19 en Afrique." Change.org. https:// www.change.org/p/les-instances-internationales-de-sant\%C3\%Ag-nonaux-tests-de-vaccins-contre-le-covid-19-en-afrique [4 June 2020]. 